\title{
Mind-Body-Spiritual Nursing Care in Intensive Care Unit
}

\author{
Ninuk Dian Kurniawati \\ Faculty of Nursing Universitas Airlangga \\ Surabaya, Indonesia \\ Ninuk.dk@fkp.unair.ac.id \\ Suharto Suharto \\ Faculty of Nursing Universitas Airlangga \\ Surabaya, Indonesia
}

\author{
Nursalam Nursalam \\ Faculty of Nursing Universitas Airlangga \\ Surabaya, Indonesia \\ nursalam@fkp.unair.ac.id
}

\begin{abstract}
The fast-paced and high technology environment coupled with high acuity and life-threatening patient conditions in intensive care unit (ICU) have led the nurse focused on professional competence and technical skills to maintain a stable physiological condition. This may result in negligence of other aspects of caring i.e. psychological and spiritual aspects. This study aimed at revealing the nurses and patients' experience on mind-body and spiritual nursing care at ICUs. The study was conducted at two hospitals: a university hospital and a private hospital in Surabaya used a phenomenological approach. The population of the study was both patients and nurses in intensive care units who were selected using purposive sampling technique. Fourteen nurses and nine patients were recruited as participants. Data collection took place from September to December 2016 by In-depth interview. Data obtained were processed and analyzed using methods of Colaizzi. Seven themes were generated from the data: patients' and nurses' perception of nursing care, patient issues, hospital environment, family support, and how patients cope with the stressors. Mind-body-spiritual nursing care is important for the patient in critical care setting to cope with the stressors. In addition to the nursing care, the patient stressors, ICU environment, family support, and experience also affect patient coping. A further study is required to establish which stimulus is significant for patient coping and what model of mind-body-spiritual nursing care is best to meet the patient need in ICU.
\end{abstract}

Keywords: mind-body-spiritual care, experience, ICU, coping, stressor Introduction

\section{INTRODUCTION}

The high technology driven critical care is focused on solving patients' physical issues that other issues may be neglected [1]. Undeniably, coronary heart disease patients treated in an intensive care unit experienced not only physical issues but also psychological and spiritual issues. Some of the prominent physical problems are the pain, thirst, sleep deprivation, shortness of breath and loss of respiratory function [2]-[4].

Psychological stressors include anxiety, perceived life threatening condition and ICU environment [4], [5]. Likewise, vigilant monitoring from nursing staff and separation from the family are perceived as the stressor for CHD respondents who were treated in ICU [4]. These may cause the patient to feel lost control and under the scrutiny of health care professionals. As a result, the patients are more vulnerable to stress. Stressinduced in the ICU can continue even after the patient has been cured and discharged from hospital [6].

Spiritually, a patient who suffers serious illness or lifethreatening condition expressed the need of seeking the meaning, understanding that there is a power beyond himself or herself and using religious practices to cope with the condition [7]. A study found that the higher the spiritual wellbeing, the lower the depression [8]. Provision of holistic nursing care is important for patient wellbeing.

Holistic care dictates that mind, body and spiritual aspects are inseparable, therefore need to be considered in planning and delivering care [1]. The aim of the study was to understand the experience of both nurses and patients regarding mind, body and spiritual nursing care in intensive care units.

\section{METHODS}

This study used a phenomenological approach to unveiling the phenomena of mind-body-spiritual care in ICUs by understanding the experiences of both patients and nurses. The population of the study was both patients and nurses in intensive care at a university hospital and a private hospital in Surabaya. Respondents were selected using purposive sampling technique. The criteria for patient respondents selection included diagnosis of coronary heart disease (CHD), Moslem, in a stable condition and be able to communicate verbally; while criteria for nurses were the minimal education of diploma three in nursing and been working in the ICU for at least 6 months.

The study was submitted to and approved by the Rumah Sakit Universitas Airlangga Ethical Committee, Number 023/KEH/2016 dated August 6th, 2016. Data collection took place from September to December 2016. In-depth interview was used for data collection technique. The interview conducted twice; the first interview was to collect data, while the second was to verify the data. To assist in the gathering of data, instruments, a field note, and a recorder were provided. 
Data obtained were processed and analyzed using methods of Colaizzi. Firstly, interviews were transcribed as a whole and be completed with the data of field note. Data were then interpreted to seek meaning and were formulated into codes. Codes were categorized and developed into themes [9][11].

\section{RESULTS}

The study involved fourteen nurses and nine patients as participants. Table 1 summarizes the characteristics of the nurses participated in the study. The majority of nurses were women $(71 \%)$, bachelor plus professional nursing educated (57\%), and had a working experience of at least 11 months. Table 2 shows that more than half of patients respondents were male $(64 \%)$ with a medical diagnosis of acute coronary syndrome and the majority have formal education.

Several themes were developed from the data. It can be seen from Table 3 that these themes were: patients' and nurses' perception of nursing care, patient issues, hospital environment, family support, and how patients cope with the stressors.

\section{TABLE 1. NURSES' CHARACTERISTIC}

\begin{tabular}{|c|c|c|c|c|c|}
\hline Code & Age & Sex & Education & $\begin{array}{c}\text { Work } \\
\text { experience }\end{array}$ & Position \\
\hline N1 & 32 yo & Male & $\begin{array}{l}\text { Bachelor + } \\
\text { Professional } \\
\text { nursing } \\
\text { education }\end{array}$ & 4 year & $\begin{array}{ll}\text { Nurse unit } \\
\text { manager }\end{array}$ \\
\hline $\mathrm{N} 2$ & 25 yo & Female & $\begin{array}{l}\text { Bachelor + } \\
\text { Professional } \\
\text { nursing } \\
\text { education }\end{array}$ & 20 month & Nurse \\
\hline N3 & 24 yo & Female & $\begin{array}{l}\text { Bachelor + } \\
\text { Professional } \\
\text { nursing } \\
\text { education }\end{array}$ & 2 year & Nurse \\
\hline N4 & 27 yo & Female & $\begin{array}{l}\text { Bachelor + } \\
\text { Professional } \\
\text { nursing } \\
\text { education }\end{array}$ & 2 year & Nurse \\
\hline N5 & 27 yo & Female & $\begin{array}{l}\text { Bachelor + } \\
\text { Professional } \\
\text { nursing } \\
\text { education }\end{array}$ & 4 year & Team Leader \\
\hline N6 & 28 yo & Female & $\begin{array}{l}\text { Bachelor + } \\
\text { Professional } \\
\text { nursing } \\
\text { education }\end{array}$ & 3 year & $\begin{array}{l}\text { Nurse } \\
\text { charge }\end{array}$ \\
\hline N7 & 24 yo & Female & $\begin{array}{l}\text { Bachelor + } \\
\text { Professional } \\
\text { nursing } \\
\text { education }\end{array}$ & $11 \mathrm{mo}$ & Nurse \\
\hline N8 & 26 yo & Male & $\begin{array}{l}\text { Bachelor + } \\
\text { Professional } \\
\text { nursing } \\
\text { education }\end{array}$ & 2 year 4 mo & $\begin{array}{l}\text { Nurse } \\
\text { Charge }\end{array}$ \\
\hline N9 & 40 yo & Male & Diploma 3 & 16 year & $\begin{array}{l}\text { Nurse unit } \\
\text { manager }\end{array}$ \\
\hline N10 & 48 yo & Male & Magister & 18 year & $\begin{array}{l}\text { Clinical } \\
\text { educator }\end{array}$ \\
\hline N11 & 29 yo & Female & $\begin{array}{l}\text { Bachelor + } \\
\text { Professional } \\
\text { nursing } \\
\text { education }\end{array}$ & 5 year & Nurse \\
\hline
\end{tabular}

\begin{tabular}{|c|c|c|c|c|c|}
\hline $\begin{array}{l}\text { N12 } \\
\text { N13 } \\
\text { N14 }\end{array}$ & $\begin{array}{l}36 \text { yo } \\
33 \text { yo } \\
33 \text { yo }\end{array}$ & $\begin{array}{l}\text { Female } \\
\text { Female } \\
\text { Female }\end{array}$ & $\begin{array}{l}\text { Diploma } 3 \\
\text { Diploma } 3 \\
\text { Diploma } 3\end{array}$ & $\begin{array}{l}11 \text { year } \\
12 \text { year } \\
9 \text { year }\end{array}$ & $\begin{array}{l}\text { Nurse } \\
\text { Nurse } \\
\text { Nurse }\end{array}$ \\
\hline \multicolumn{6}{|c|}{ TABle 2. PATIENTS' CHARACTERISTIC } \\
\hline Code & Age & Sex & Education & $\begin{array}{c}\text { Length of } \\
\text { Hospitalization }\end{array}$ & $\begin{array}{c}\text { Medical } \\
\text { Diagnosis }\end{array}$ \\
\hline $\mathrm{P} 1$ & 65 yo & Male & $\begin{array}{l}\text { Junior High } \\
\text { School }\end{array}$ & 5 days & $\begin{array}{l}\text { STEMI } \\
\text { anterior }\end{array}$ \\
\hline P2 & 68 yo & Female & No education & 5 days & UAP \\
\hline P3 & 50 уо & Female & Bachelor & 3 days & TVD+ Angina \\
\hline P4 & 61 yo & Male & $\begin{array}{l}\text { Senior High } \\
\text { School }\end{array}$ & 4 days & IMA Anterior \\
\hline P5 & 67 yo & Male & $\begin{array}{l}\text { Junior High } \\
\text { School }\end{array}$ & 10 days & $\begin{array}{l}\text { STEMi } \\
\text { Inferior Killip } \\
2\end{array}$ \\
\hline P6 & 51 уо & Male & Bachelor & 6 days & NSTEMI \\
\hline P7 & 40 yo & Male & Bachelor & 5 days & $\begin{array}{l}\text { STEMI } \\
\text { Inferior }\end{array}$ \\
\hline P8 & 62 yo & Female & $\begin{array}{l}\text { Senior High } \\
\text { School }\end{array}$ & 6 days & NSTEMI \\
\hline P9 & 69 yo & Male & $\begin{array}{l}\text { Senior High } \\
\text { School }\end{array}$ & 7 days & NSTEMI \\
\hline
\end{tabular}

\section{A. Nursing Care}

There are differences in the perception of the needs of patients in nursing care and nursing care given by nurses. Nurses consider psychosocial and spiritual problems can be ruled out due to physical problems more life threatening, except when the patient is in a terminal condition.
"Mmm .. here we focus on airway and breathing which are more problematic, we provide spiritual nursing care mainly on palliative patients." (N2)
"Eeee .. We've done it but not to every patient, for instance, we know the patient is in end-stage, cannot be helped, we approach the family so that the patients died peacefully. "(N6)

In contrast, patients reveal that they need the nurse to help them not only with physical issues but also psychosocial and spiritual needs.

"For me, it is very important Ma'am, mainly psychological and spiritual, spiritual for me is very important; I want to keep doing the religious activities."(P3)

"I assume because there are too many things a nurse should handle, they have less time to ask my problem. Some nurse might ask whether I feel chest pain. They did not have much time to ask or pay attention to other aspects, such as stress I experienced, which is very disturbing. "(P3)

"Examine the psychosocial and spiritual issues of the patient unless it is prominent like they cried or express anger."(N9) 
"The only things so far to address the psychosocial problems are giving information and motivation." (N1)

"There was once a patient with the psychological problem; he became grumpy and abusive. At first, we tried to calm him, following what he wants, ignore his anger and his coarse language, you know, He was a sick man after all. Then get worse and worse that we consulted him to a psychiatrist because he refused all treatments, including nutrition; can you believe that we had to insert the feeding tube three times a day because he kept pulling it?" (N4)

Similarly, respondents also recognized that the nurses are still lacking in meeting the spiritual issues. Nurses understand that the provision of spiritual care is important, but it is not done routinely. The nurses will help the patient with the spiritual need mainly by orienting the patients to the prayer times and if the patient asks them to do so. Nurses also recalled zikr and religious song as part of the intervention.

"So far what I've done was merely remind the prayer time for Muslim patients while for Christian patients I encouraged the family to bring MP3 with spiritual songs." $(N 8)$

"Some nurses are often reminiscent of the prayer time (P1, P2)."

"There was a fully-grown male patient who was very agitated, I suggested him to zikr of astaghfirullahaladzim, he then became calmer." (N2)

Discussion, both nurses and patients, agree that despite its importance, most nurses fail to meet all patient needs. Not all nursing assessment covers patient problems holistically; however if the sign of psychological distress is so prominent, the intervention is performed, mainly in the form of providing the patient with information and motivation. The nurse will also consult with the psychiatrist if the patients get worse.

"Holistic services that include bio-psycho-sociospiritual, mmm... not all are given." (N9, N10, N11)

"I think I've been focusing on physical and technical skills too much." (N8)

TABLE 3. THEME GENERATED FROM THE STUdy

\begin{tabular}{lll}
\hline Categories & Sub Themes & Themes \\
\cline { 1 - 1 } Pain and discomfort & $\begin{array}{l}\text { Physics- } \\
\text { biologic }\end{array}$ & \\
\cline { 1 - 1 } Shortness of breath & Psycologic & $\begin{array}{l}\text { Patients' issues/ } \\
\text { stressors }\end{array}$ \\
\cline { 1 - 1 } Limp & Role disfunction & \\
\cline { 1 - 2 } Anxiety and fear & Spiritual & \\
\cline { 1 - 2 } $\begin{array}{l}\text { Fnable to perform religious } \\
\text { rituals }\end{array}$ & Assessment & Nursing care \\
\hline Physical assessment & &
\end{tabular}

\begin{tabular}{|c|c|c|}
\hline Categories & Sub Themes & Themes \\
\hline Psychological assessment & & \\
\hline Spiritual assessment & & \\
\hline $\begin{array}{l}\text { Giving therapy, } \\
\text { observation }\end{array}$ & \multirow{2}{*}{$\begin{array}{l}\text { Physical } \\
\text { intervention }\end{array}$} & \\
\hline Helping with basic needs & & \\
\hline Giving information & \multirow{3}{*}{$\begin{array}{l}\text { Facilitate } \\
\text { coping }\end{array}$} & \\
\hline Refer to psychiatrist & & \\
\hline Reduce stress & & \\
\hline Remind prayer time & \multirow{3}{*}{$\begin{array}{l}\text { Fascilitate } \\
\text { spiritual } \\
\text { activities }\end{array}$} & \\
\hline Dzikir and dua & & \\
\hline $\begin{array}{l}\text { Help with prayer } \\
\text { preparation }\end{array}$ & & \\
\hline Comfort room & $\begin{array}{l}\text { Physical } \\
\text { condition }\end{array}$ & \multirow{3}{*}{$\begin{array}{l}\text { Hospital } \\
\text { environment }\end{array}$} \\
\hline Communication & \multirow{2}{*}{$\begin{array}{l}\text { Psychosocial } \\
\text { conditions }\end{array}$} & \\
\hline Nursing hospitality & & \\
\hline Emotional & & \multirow{3}{*}{ Family support } \\
\hline Cognitive & & \\
\hline Material & & \\
\hline Nursing care experience & & \multirow{2}{*}{ Past experience } \\
\hline The effectivity of coping & & \\
\hline $\begin{array}{l}\text { Solve the problem in a } \\
\text { planned manner }\end{array}$ & \multirow{4}{*}{$\begin{array}{l}\text { Solve the } \\
\text { problem }\end{array}$} & \multirow{8}{*}{ Coping } \\
\hline Direct action & & \\
\hline Asking for help & & \\
\hline Information seeking & & \\
\hline Avoidance & \multirow{4}{*}{$\begin{array}{l}\text { Try to do } \\
\text { something else }\end{array}$} & \\
\hline Deny & & \\
\hline Self-criticism & & \\
\hline Looking for silver lining & & \\
\hline
\end{tabular}

\section{B. Patients Issues}

Patient issues or stressors significantly affect the result of the nursing care. Several categories fall into this theme: physical issues, psychological issues, and spiritual issues. Pain and discomfort are physical issues that most complained by the patient. For some patients, this complaint affects coping skills and is a source of anxiety.

"Pain made me fear because it was accompanied with difficulty to draw breath" (P2, P8). Shortness of breath is also a source of anxiety for the patient, as expressed by the patient: "I was brought to the hospital due to shortness of breath. I was so scared that I was going to die that day." (P2, P3).

Weakness is another complaint which makes the patients feel lost control over them, as supported by the following statement:

"I felt limp, so weak I could barely stand up, I couldn't do anything, and nurses have helped me a lot. I usually can do everything by myself, depending on other makes me feel uncomfortable"

Moreover, patients also experience some psychological issues that affect patients physically, as disclosed by a patient,

"I was so scared because the patient next to me died, my blood pressure rose instantly." (P1).

Psycho-social issues experienced by patients include but not limited to role stress, anxiety, and family issues. A patient expressed an example: 
"I usually busy working; many people depend on me. I am here, doing nothing. Time is running very slowly here; a day is not 24 hours, but 72 hours." (P7)

Fear of death or leaving loved ones, anxiety about treatment option, and family issue are some of the stressors revealed by the respondents.

"Frankly, I was admitted to hospital after consulting with the doctor. Ifeel so tense; the doctor said there are seven blockages in blood vessels that require a surgical bypass, otherwise...(long pause), fear of pain, fear of death, I've seen some videos on youtube about bypass surgery, I really don't know what to do. "(P3).

"My daughter is insisted on marrying an uneducated guy who only a seller in a traditional market, I am so concern about her future. Yet she is so determined to marry him; she threatened me and her dad of leaving the school and not finish her thesis if we don't agree with a man she loves so much." (P6)

Spiritual is described as a religion by patients. Spiritual issues stemmed from obstacles in performing religious rituals. These include difficulty in prayer, confused about prayer time, difficulty in performing ablutions before prayer and feel dirty and impure thus unable to perform prayer.

"I cannot pray here, how can I pray with a dirty body like this, catheters, possibly dirty bed?" (P8, P9)

\section{The Hospital Environment}

Hospital environment both physically and psychologically can be the source of a stressor for patients. The physical condition includes the room comfort, indoor temperature, and the noise level. The psychological conditions that affect patients are nurses' communication skills and hospitality.

"Some patients complain about the air conditioning; they say it is too cold." (N7, N8 N13). "Nurses were very friendly and extremely skillful." (P7, P3)

"I wish all of them can talk in a soothing voice and spend more time with me." (P7)

\section{Family Support}

Family support is important for patients. Family and loved ones can reduce the patient's anxiety and sadness. Emotional, informational and material supports are expected during ICU stay; however, the limitations of family visits make it difficult for the family to provide necessary support for the patient. Samples of statements are provided below:

"Surely requires the family to be around, more than anything. The ICU environment was so overwhelming, all that machines and tubes, but they cannot see me very often, they have to wait outside." (P4, P7)

"If a patient looks sad, we usually call the family to provide support to the patient. I work most of the time." (N9, N12)

"Need the family to be able to sort things out." (P3)

\section{E. Experience}

A positive experience during the previous hospitalization can help patient cope with current stressors. However, some patients suggest that it is difficult for them to use the experience to deal with the current stressor if the experience and the current issues are vastly different.

"Hospitalised with the same symptom last year, I know what to expect now." (P8)

"A nurse taught me how to divert my attention from the pain, I did it but it didn't work. Maybe because the disease is getting severe" $(P 7)$

"Yes, once, long time ago, because of fever. Nothing compared to current shortness of breath." (P2)

\section{F. Coping Strategy}

There is two type of coping styles identified from this study: solve the problem and doing another thing that involves emotional response. Directing energy and resources to solve the problem were done by seeking help from other and seeking information; although none of the participants made a plan to solve the problem.

"There's no plan Ma'am, just follow what the doctors and nurses told to do." (P2, P5, P9).

"I have been discussing options with husband and my daughter; they said whatever I choose, they will support me." (P3)

"We talked with the doctor, he recommended surgery, but I can't make up my mind until now. I've also been looking for information on youtube, ask friends. "(P3)

Many respondents are using coping mechanisms that focus on emotional responses. Negative emotional responses used by respondents were anger, self-blame, and denial, while the positive emotional response was seeking for meaning.

"Some patients expressed their stress with anger and being abusive; I remember there was a patient who hit and pinch nurses." (N3, N8)

"I slept a lot, try to forget the problem." (P6)

"It's all my fault, I should never let my wife took care of me in the hospital in the first place, she became too tired and fainted, she was taken to the ER..."

"I always believe that every cloud has a silver lining, I am trying to contemplate the meaning of my sickness." (P9) 


\section{DISCUSSION}

In the ICUs, the challenge is to provide a holistic care because psychological and spiritual issues of patients are considered less important. This study revealed that psychological and spiritual care were compromised over physical and physiological care. Adversely, patients expressed the importance of both psychological and spiritual care as well as physical and physiological care. Therefore a mind-bodyspiritual nursing care is a logical answer to this phenomena. Nurse must perform a holistic nursing care assessment to deliver a mind-body-spiritual nursing care. This assessment will lead the nursing intervention that tailored to meet the patient specific needs.

Patient's constructive coping is pivotal for ICU patients. As yielded from the study that patient coping was affected by nursing care, hospital environment, family support, and past hospital environment; therefore a nurse must be aware of all these aspects and, if possible, modified these aspects to promote constructive coping. An intervention that merely consists of vigilant monitoring, giving physician orders, documenting and reporting are highly inadequate to help the patient cope with the issues.

This study asserts that although holistic nursing care assessment was hardly done, the psychological intervention was provided for the distressed patient. The interventions were education and sought support from patients' family. This finding is consistent with the literature explain that personal support of family and significant others play a crucial role in patient well-being and recovery [1], [12]. Family support ranks the third of Maslow's hierarchy of needs for critically ill patients during an ICU stay [13]. The family provides the patient a source of emotional support [14]. Due to its importance, the nurse must prepare the family to be able to help the patient. The nurse must support the family with necessary information on disease process and treatment plan and how the family can best support the patient. Involvement of family member in nursing care without adequate support from nursing staff may trigger stress to the family [15]. reported family stress in their study. Similarly, Olsen found that for family, seeing the family member in critically ill conditions was stressful [14]. Family stress may impede the family ability to provide adequate support.

Furthermore, this study found that spiritual care is needed as patients seek for meaning and guidance in critical and unpredictable condition. Spiritual care should be delivered based on the patient need, thus assessment is again very important. A study found that talking to patients and their families, listening to them, and observing the surrounding environment helped nurses to identify spiritual needs of patients [16]. For Moslem patients, spirituality is inseparable with religion; thus religious activity such as prayer during illness is one of their basic needs. For Moslem, Prayer is not only an obligation but also help them cope with uncertain and life threatening situations in ICU. This study is consistent with the previous literature which stated that prayer is a powerful complementary treatment in several settings [17], [18]. rayer promotes the sense of hope and improve patient health [19]. Also, to remind the prayer time, patients said that they want nurses to help them with the prayer preparation, such as ablution, clean the bed and dress properly for the prayers.

\section{CONCLUSION AND RECOMMENDATION}

Mind-body-spiritual nursing care is important for the patient in the critical care setting to cope with the stressors. In addition to the nursing care, the patient stressors, ICU environment, family support, and experience also affect patient coping. A further study is required to establish a model of mind-bodyspiritual nursing care that is best meet the patient need.

\section{REFERENCES}

[1] L. Urden, K. Stacy, and M. Lough, Critical Care Nursing Diagnosis and Management. St Louis Missouri: Mosby Elsevier, 2010.

[2] M. Baird and S. Bethel, Manual of Critical Care Nursing. Nursing Interventions and Collaborative Management, 6th ed. St. Louis Missouri: Mosby Elsevier, 2011.

[3] A. Garrido, A. Gonzales, and G. Garcia, "Stressful Environmental Events in the Intensive Care Unit," Enferm Intensiva, vol. 18, no. 4, pp. 159-167, 2007.

[4] D. Dias, M. Resende, G. Carmo, and L. Diniz, "Patient stress in intensive care : comparison between a coronary care unit and a general postoperative unit," Rev Bras Intensiva, vol. 27, no. 1, pp. 18-25, 2015.

[5] P. Morton and D. Fontaine, Essentials of Critical CareNursing: a Holistic Approach. Philadelphia: Wolter Kluwer Lippincott Williams \& Wilkins, 2013.

[6] J. Davidson, M. Harvey, J. Schuller, and G. Black, "Post-intensive Care Syndrome: What it is and How to Help Prevent It.," Am. Nurse Today, vol. 8, no. 5, p. 32, 2013.

[7] D. A. Westera, Spirituality in Nursing Practice: The Basics and Beyond. New York: Springer Publishing Company, 2017.

[8] R. Mirwanti and A. Nuraeni, "Hubungan Kesejahteraan Spiritual dengan Depresi Pada Pasien Dengan Penyakit Jantung Koroner (PJK)," Medisains, vol. 14, no. 1, Sep. 2016.

[9] Afrizal, Metode Penelitian Kualitatif. Jakarta: Rajawali Press, 2014.

[10] N. Burns and S. Grove, Introduction to the Qualitative Research Process. Maryland: Saunders Elsevier, 2011.

[11] G. A. Shosha, "Employment of Collaizzi's Stratgegy in Descriptive Phenomenology: A Reflection of A Researcher," Eur. Sci. J., vol. 8, no. 27, pp. 31-43, 2012.

[12] O. Tara, "Developing Family Support Group in the ICU," Nurs. Crit. Care, vol. 5, no. 5, pp. 33-37, 2010.

[13] L. V. Karnatovskaia, O. Gajic, O. J. Bienvenu, J. E. Stevenson, and D. M. Needham, "A holistic approach to the critically ill and Maslow's hierarchy," J. Crit. Care, vol. 30, no. 1, pp. 210-211, 2015. 
[14] K. Olsen, E. Dysvik, and B. Hansen, "The Meaning of Family Members' Presence During Intensive Care Stay: A Qualitative Study," Intensive Crit. Care Nurs., vol. 25, pp. 190-198, 2009.

[15] S. Beesley, S. Brown, R. Hopkins, E. Wilson, J. Butler, K. Kuttler, J. Orme, and E. Hirshberg, "Stress In Family Members Of ICU Patients," Crit. Care Med., vol. 43, no. 12, p. 141, Dec. 2015.

[16] N. Abu-El-Noor, 'ICU Nurses' Perceptions and Practice of Spiritual Care at the End of Life: Implications for Policy Change," Online J. Issues Nurs., vol. 21, no. 1, pp. 1-10, 2016.
[17] P. Chui, K. Abdullah, L. Wong, and N. Taib, "Prayerfor-health and Complmentary Alternative Medicine Use Among Malaysian Breast Cancer Patients During Chemotherapy," BMC Complement. Altern. Med., vol. 14, p. 425, 2014.

[18] M. Holt-Ashley, "Nurses pray: use of prayer and spirituality as a complementary therapy in the intensive care setting.," AACN Clin. Issues, vol. 11, no. 1 , pp. $60-7$, Feb. 2000.

[19] M. Doucet and M. Rovers, "Generational Trauma, Attachment, and Spiritual/Religious Interventions," $J$. Loss Trauma, vol. 15, no. 2, pp. 93-105, 2010. 